\title{
Computer Assisted Radiology—26th International Congress and Exhibition
}

Chairman: Stanley Baum, MD (USA), Co-Chair: Carlo Bartolozzi, MD (I) 